\title{
COMPUTER ETHICS OF AMERICAN AND EUROPEAN INFORMATION TECHNOLOGY STUDENTS: A CROSS-CULTURAL COMPARISON
}

\author{
Nancy L. Martin, Southern Illinois University, nlmartin@siu.edu \\ Belle Woodward, Southern Illinois University, bellew@siu.edu
}

\begin{abstract}
In recent years, computer ethics has drawn increasing interest from practitioners as well as from academicians. Despite repeated calls in literature for cross-cultural research in this age of globalization, few studies have examined the ethical decision making tendencies of European IT students compared to American IT students. Using IT-related ethical dilemma scenarios, this article investigates the personal ethical decisions of American and European students and finds that significant differences exist in half of the scenarios. The study also finds significant differences in the rating of the ethicality of the scenarios with American students rating most scenarios as more unethical than their European counterparts.
\end{abstract}

Keywords: Information Technology (IT), Ethics, IT and Ethics, Cultural Comparison, IT Students

\section{INTRODUCTION}

Computer and internet usage are a part of students' daily routines, in part because many have grown up with the technology, and these students will become tomorrow's workforce. Such technologies are integrated into daily communication habits and have become as ordinary as the telephone or television. At the same time, organizations and individuals have become increasingly concerned with a host of ethical issues created by the interconnected world. Concerns about piracy, privacy, misuse of computer resources, and even criminal activity abound. There has been considerable media attention on software piracy and the illegal downloading of music, which is especially prevalent among college-age students. For example, a 2007 report by the U.S. House of Representatives states that $34 \%$ of college students illegally download music from file sharing networks [34]. The report also states that NPD Group, a leading entertainment research firm, found that more than two-thirds of music acquired by college students was obtained illegally, and that students are more than twice as likely as the general population to use file sharing networks to download music.

Of even greater concern is that ethical issues in computing are not bound by geographic area. The Business Software Alliance (BSA) reports that in 2009, overall worldwide software piracy was on the rise, especially in emerging economies. While some regions saw lower or level piracy rates, others regions' rates rose or stayed at dramatically high levels [5]. Academics have also documented that piracy and other information technology (IT) related ethical issues occur across nations and cultures. Moores and Dhillon report that 81 percent of students surveyed in a Hong Kong university admitted buying pirated software [24]. Siponen and Vartiainen found that 72.5 percent of Finnish students surveyed had copied unauthorized software [31]. More recently, Gerlach et al. [12] found that Chinese students were less concerned than U.S. students about legal sanctions of copyright infringement, thereby contributing to China's high rate of piracy.

As research has established, IT-related ethical issues are prevalent around the globe. As future IT professionals, students enrolled in technology curriculums will almost certainly find themselves faced with ethical dilemmas sometime in their career. Also, because the trend toward a globalized economy continues, many of today's students will find themselves working with individuals of different nationalities and it will become increasingly important to understand how different individuals respond to ethical concerns. This article presents the results of a survey of undergraduate IT students from the U.S. and three European countries. The survey questioned the students about the ethicality of various IT practices and their perceived intentions if they should encounter such a situation. The views of the American students were then compared to those of the European students to explore consistencies and differences. 


\section{Issues in Information Systems}

Volume XII, No. 1, pp. 78-87, 2011

\section{LITERATURE REVIEW}

\section{Computer Ethics Defined}

Ethics refers to standards of behavior that communicate how human beings should act in the many situations in which they find themselves: as friends, parents, children, citizens, teachers, or professionals. "Computer ethics" was first commonly defined by Walter Maner in the mid-70s as the field of study that examines ethical problems intensified, transformed or created by computer technology [22]. Other scholars have further defined the concept of computer ethics over time [e.g. 13, 16]. A broad definition developed by Bynum [6], and used for this research, is that computer and information ethics can be defined as the branch of applied ethics which studies and analyzes the social and ethical impacts of information and communication technology.

\section{Ethical Issues in IT}

In 1986, Mason introduced four broad categories of information era ethical issues: privacy, accuracy, property, and access, otherwise known as PAPA [23]. Twenty years after Mason's ethical issues essay, Peslak [29] surveyed more than 200 individuals and verified that the four original PAPA issues were still viewed as timely and important ethical concerns.

Using ethical dilemma scenarios, Conger, Loch, and Helft [9] conducted research that produced five clusters of ITrelated ethical issues. Two of the five clusters represented issues of responsibility and motivation which were not addressed in Mason's essay. Whitman, Townsend, and Hendrickson [35] also used ethical dilemma scenarios, adding to those first developed by Paradice [27]. A factor analysis of responses revealed three categories of issues: software license infringement, illicit use such as hacking and viruses, and misuse of corporate resources. Those categories were used to compare ethical tolerance levels of students from eight countries.

The broad groupings of issues identified in prior research encompass a variety of specific illegal, unethical, or questionable practices. For example, the use of pirated software, a property issue, is pervasive at universities and may even be happening in classrooms [19]. Other studies found that students viewed making copies of protected software as socially and ethically acceptable [8, 32]. Kini et al. considered softlifting, illegal copying of software for personal use, even more prevalent in universities than in the general population [18]. A survey sponsored by the BSA indicated that 52 percent of university student respondents in the United States and 25 percent of academics believed that the use of pirated software (swapping or downloading digital copyrighted files such as software, music, and movies without paying for them) was acceptable, even in the workplace [4].

Sources indicate that students in general have a greater tendency towards pirating software and other intellectual property $[17,19]$. However, it is not necessarily the college environment that promotes the downloading of software. An older study looking at non-university subjects came to the same conclusion, that "young professionals have no scruples about copying software illegally" [26, p. 26]. More recently, it was revealed that software cost and the severity and certainty of punishment for piracy may determine how likely individuals are to commit the act in the workplace [28]. A study by Freestone and Mitchell found Generation Y consumers were more permissive of piracy because many reasoned that they were doing no direct harm to sellers, and were victims of inflated music prices [11].

Although the specific scenarios and dilemmas faced by students and professionals may change due to technological advances, it appears that broad categories of common ethical issues in IT remain fairly constant.

\section{Ethical Decision Making}

It is widely accepted that ethical issues arise or are altered due to the ubiquity of technology. Therefore, many people, and especially IT professionals and students, will likely face situations where a choice of action must be made. While, a great deal of research examines why and how individuals make certain decisions when faced with ethical dilemmas in a general environment, this research focuses on the ethical decision making of IT students in 
specific scenarios and adopts a recently proposed definition of ethical judgment as "an individual's personal evaluation of the degree to which some behavior or course of actions is ethical or unethical” [33, p. 409].

Prior research in this specific domain has been informative. Peslak [30] studied IT professionals' and IT faculty and students' attitudes toward common IT-related unethical behaviors such as copying software, downloading and distributing music, and accessing private information. He found that individuals were less opposed to property violations for personal use than when the violations were for distribution purposes. Peslak also discovered that the extent of consequences was an important influence in ethical decision making.

\section{Cross-cultural Differences}

Previous research has focused on the differences in ethical decision making across cultures or nations, with recent research documenting the presence of these differences [1, 2, 3]. Ford and Richardson [10], Loe et al. [20], and O'Fallon and Butterfield [25] have written reviews of the empirical literature on ethical decision making. The majority of this research has concluded that culture does influence one's ethical actions.

Chung et al. studied the differential ethical perceptions of East Asian and U.S. business students. Based upon their responses to business scenarios and questions regarding the effects of ethical business behavior, it appeared that U.S. students were much more cognizant of the need for ethical behavior in business [7]. Kini et al. [17] found that Thai students were more likely to commit software piracy than U.S. students. Hilton et al. [15] compared the ethical attitudes of bank employees from the U.S., Oman, and South Korea and found that U.S. subjects believed employer monitoring of company resources to be ethical, while the other subjects found the practice to be unethical. Regarding various personal uses of employer IT resources, there were differing degrees of the level of acceptance among the three nationalities.

Specific to IT scenarios, Whitman et al. [35] found that among students surveyed from eight countries, there was general agreement about what constitutes acceptable behavior in terms of copyright infringement, illicit computer use such as hacking and viruses, and the misuse of corporate resources. However, in exploring specific scenarios, the researchers found that the American students were less tolerant of copyright infringement than most other countries in the study.

The purpose of this study was to explore potential differences in the IT-related ethical decision making of students from the U.S. and some European countries. Ethical issues in IT continue to prevail and evolve. While there has been considerable research conducted to compare ethical decision making in a business environment and across cultures, little research has focused on the IT-specific ethical decision making of European subjects [31].

After an extensive review of previous research, the following research questions were formulated as the basis for this study.

1) Do American and European students perceive different levels of ethicality in IT-related ethical dilemma scenarios?

2) Do personal ethical decisions differ between American and European students with regard to ITrelated ethical dilemmas?

\section{METHODOLOGY}

A well accepted method for evaluating how students make ethical decisions is to confront them with ethical dilemmas or situations [21]. After an extensive review of the literature, an existing survey instrument was selected to evaluate the ethical decisions of information technology students [14]. The instrument, referred to as the Ethics in Information Technology (IT) Survey, was used with the author's permission.

The survey for this study contained 20 scenarios with two of the scenarios from more than one person's perspective for a total of 22 items. The detailed wording of the scenarios was published as part of earlier study [36] and is shown in Appendix A along with a short name for each scenario. These scenarios were used to determine students' 
perceptions of the ethicality of various situations. In the scenarios, an anonymous individual was presented with a situation and was required to make a choice for a particular action. The students were asked to evaluate the given individual's response to the situations presented. They were to mark a scale number indicating whether they felt the individual's actions were ethical (0), acceptable (1), questionable (2), unethical (3), or a computer crime (4). The descriptors of the scale are described as:

- Ethical - There is no question that the action is correct in every sense of the word. Ethically, morally, and legally, this is proper behavior.

- Acceptable - The action is acceptable to you, although you may have some doubts due to morals or other beliefs.

- Questionable - There is some question as to the moral or ethical aspects of the action. The action truly belongs in the "gray area" of human behavior.

- Unethical - The action is contrary to moral and ethical standards, although not a crime. This is truly unacceptable behavior.

- Computer Crime - The action is unethical and illegal, and the person responsible should be prosecuted for a criminal act (Harris, 2000).

To further understand the ethical decision making of IT students, a second type of question was presented in the survey. The first type of question, just described, asked students to rate the ethicality of the scenarios according to the scale above. The second type of question addressed behavior, and asked the students if they would act similarly to the individual in the scenario if they found themselves in the same situation.

The survey was administered to a total of 319 undergraduate IT students during the fall of 2008. One hundred fortyfour students were from an American Midwest region university, 44 were from a British university, 51 were from a German university, and 80 were from an Italian university. The survey instrument was translated into both German and Italian. The purpose and procedures of the survey were explained to the students by the same faculty member for all sites. The students participated voluntarily and were ensured of the confidentiality of their responses, and all surveys were completed anonymously.

Out of the total sample, $18.8 \%$ were female students $(\mathrm{N}=57)$ and $81.3 \%$ were male students $(\mathrm{N}=247)$. Fifteen students did not report gender. The gender breakdown is shown in Table 1. The average age for the sample was 24.2 years for American students and 22.7 years for European students. The median age for both groups was 22 years.

Table 1. Demographics

\begin{tabular}{|l|l|l|l|}
\hline & America & Europe & Total \\
\hline Male & 111 & 136 & 247 \\
\hline \% within continent & $79.90 \%$ & $82.40 \%$ & $81.30 \%$ \\
\hline Female & 28 & 29 & 57 \\
\hline \% within continent & $20.10 \%$ & $17.60 \%$ & $18.80 \%$ \\
\hline Total & 139 & 165 & 304 \\
\hline
\end{tabular}

\section{RESULTS}

The first research question focused on potential differences in how the two groups of IT students rate the ethicality of ethical dilemma scenarios. Table 2 displays the mean rating for each scenario and is divided by student group. Recall that a score of 0 indicated an ethical action and 4 indicated the worst action, a computer crime. Also reported in Table 2 are the results of the nonparametric tests of means. The distributions of the ethicality ratings of the scenarios were not expected to be normal and statistical tests confirmed that assumption. Therefore, the comparisons were conducted using Mann-Whitney tests. Mann-Whitney tests are calculated on the sample medians rather than means, and are appropriate when comparing two unpaired samples that are not assumed to have normal distributions. 
Volume XII, No. 1, pp. 78-87, 2011

In 16 of 22 scenarios, the ethicality rating was significantly different between the American and European students. The significantly higher mean is indicated by an asterisk in Table 2. Further analysis of the 16 differing ratings revealed that the American students rated the scenarios higher, or more unethical, in 13 instances. Referring to the short titles used in Table 2, these 13 included Send Critical Email -Employee, Change Bank Account Status, Refuse to Register Shareware, Copy Word Processing Program, Share Password, Generate Inaccurate Data, Fail to Report Interest Error, Copy Spreadsheet Package for Home, Access Payroll Records, Use Company PC, View Porn Sites at Work, Use Company PC for Offshore Gambling, and Use Trademarks without Permission. European students rated the following scenarios higher on the scale than the American students: Review Critical Email Manager, Send Email SPAM, and Fire Porn Site User.

Table 2. Comparisons of Ethicality Ratings

\begin{tabular}{|c|c|c|c|c|}
\hline & American & European & & \\
\hline Scenario & Mean & Mean & $\begin{array}{c}\text { Mann- } \\
\text { Whitney }\end{array}$ & $p$ \\
\hline $\begin{array}{l}\text { Review Critical } \\
\text { Email -Manager }\end{array}$ & 1.35 & $2.25 *$ & 10473.50 & .000 \\
\hline $\begin{array}{l}\text { Send Critical } \\
\text { Email-Employee }\end{array}$ & $2.18^{*}$ & 1.91 & 13309.5 & .001 \\
\hline $\begin{array}{l}\text { Change Bank } \\
\text { Account Status }\end{array}$ & $2.80 *$ & 2.51 & 14876.50 & .019 \\
\hline $\begin{array}{l}\text { Refuse to Reg } \\
\text { Shareware }\end{array}$ & $2.38^{*}$ & 1.86 & 11708.00 & .000 \\
\hline $\begin{array}{l}\text { Copy Word Proc } \\
\text { Program }\end{array}$ & $1.80^{*}$ & 1.17 & 12109.00 & .000 \\
\hline $\begin{array}{l}\text { Change Class } \\
\text { Data }\end{array}$ & 3.10 & 3.28 & 11239.50 & .132 \\
\hline Share Password & $2.34 *$ & 1.96 & 14005.00 & .003 \\
\hline $\begin{array}{l}\text { Spread Virus for } \\
\text { Test }\end{array}$ & 2.34 & 2.26 & 16153.00 & .461 \\
\hline $\begin{array}{l}\text { Generate } \\
\text { Inaccurate Data }\end{array}$ & $2.40^{*}$ & 1.77 & 10854.50 & .000 \\
\hline $\begin{array}{l}\text { Send Email } \\
\text { SPAM }\end{array}$ & 2.52 & $2.91^{*}$ & 14251.50 & .009 \\
\hline $\begin{array}{l}\text { Reprimand } \\
\text { SPAM Sender }\end{array}$ & 1.84 & 2.30 & 16096.50 & .618 \\
\hline $\begin{array}{l}\text { Fail to Report } \\
\text { Interest Error }\end{array}$ & $3.06 *$ & 2.95 & 14663.500 & .014 \\
\hline $\begin{array}{l}\text { Copy } \\
\text { Spreadsheet Pkg }\end{array}$ & $1.86 *$ & 1.17 & 10942.50 & .000 \\
\hline $\begin{array}{l}\text { Release } \\
\text { Shareware Virus }\end{array}$ & 3.49 & 3.52 & 16163.00 & .549 \\
\hline $\begin{array}{l}\text { Access Payroll } \\
\text { Records }\end{array}$ & $2.93 *$ & 2.45 & 11168.00 & .000 \\
\hline $\begin{array}{l}\text { Use Company } \\
\text { PC }\end{array}$ & $2.43 *$ & 2.14 & 13786.00 & .006 \\
\hline $\begin{array}{l}\text { Create Website } \\
\text { to Collect } \\
\text { Personal Data }\end{array}$ & 2.71 & 2.86 & 14685.00 & .119 \\
\hline $\begin{array}{l}\text { Fire Porn Site } \\
\text { User }\end{array}$ & $2.83 *$ & 2.43 & 11472.00 & .000 \\
\hline $\begin{array}{l}\text { View Porn Sites } \\
\text { at Work }\end{array}$ & 1.27 & $2.06^{*}$ & 10188.00 & .000 \\
\hline $\begin{array}{l}\text { Use Company } \\
\text { PC for Gambling }\end{array}$ & $2.26 *$ & 2.11 & 14052.00 & .023 \\
\hline $\begin{array}{l}\text { Use Trademarks } \\
\text { w/o Permission }\end{array}$ & $3.45^{*}$ & 3.37 & 14260.00 & .044 \\
\hline $\begin{array}{l}\text { Make \& Sell } \\
\text { Music CD }\end{array}$ & 3.11 & 3.21 & 14924.00 & .267 \\
\hline
\end{tabular}

The second research question of this study focused on whether the personal ethical decisions made in response to the scenarios would differ between the American and European students. The students were asked if they would act similarly to the individual in the scenario if they found themselves in the same situation. Answers were recorded as 
Volume XII, No. 1, pp. 78-87, 2011

yes/no responses and coded accordingly. Chi-square tests were performed to explore whether the two groups of students differed significantly in how they would act in a similar ethical situation.

American and European students provided similar responses in half of the scenarios. However in 11 of the 22 questions, the two groups' responses were significantly different. Table 3 displays the percentage of yes answers for each group. The scenarios marked with an asterisk reflect those that were significantly different between the groups $(p<.05)$.

Table 3. Personal Action Decisions of American and European Students

\begin{tabular}{|l|c|c|}
\hline \multirow{2}{*}{} & American & European \\
\cline { 2 - 3 } & Yes\% & Yes\% \\
\hline Review Critical Email -Manager* & 54 & 38.2 \\
\hline Send Critical Email-Employee & 27.8 & 37.3 \\
\hline Change Bank Account Status & 33.3 & 39.5 \\
\hline Refuse to Register Shareware* & 64.9 & 80.9 \\
\hline Change Class Data & 81.1 & 87.9 \\
\hline Share Password* & 10.2 & 10.5 \\
\hline Spread Virus for Test & 32.8 & 49.4 \\
\hline Generate Inaccurate Data* & 30.8 & 32.2 \\
\hline Send Email SPAM & 37.6 & 68.5 \\
\hline Reprimand SPAM Sender & 12.8 & 9.4 \\
\hline Fail to Report Interest Error* & 53.6 & 53.3 \\
\hline $\begin{array}{l}\text { Copy Spreadsheet Pkg for } \\
\text { Home* }\end{array}$ & 7.1 & 16.3 \\
\hline Release Shareware Virus & 72.8 & 85.3 \\
\hline Access Payroll Records* & 6.6 & 11.8 \\
\hline Use Company PC * & 20.7 & 43.5 \\
\hline $\begin{array}{l}\text { Create Website to Collect } \\
\text { Personal Data }\end{array}$ & 35.1 & 51.2 \\
\hline Fire Porn Site User* & 15.3 & 21.4 \\
\hline View Porn Sites at Work* & 61.1 & 40.6 \\
\hline $\begin{array}{l}\text { Use Company PC for Offshore } \\
\text { Gambling }\end{array}$ & 36.8 & 24.8 \\
\hline $\begin{array}{l}\text { Use Trademarks without } \\
\text { Permission }\end{array}$ & 36.1 & 8.3 \\
\hline Make and Sell Music CD* & 21.3 \\
\hline
\end{tabular}

The difference between American students and European students was significant in the following scenarios:

- Review Critical Email. Table 3 shows that 54\% of American students would reprimand the employees sending such e-mails compared to $38.2 \%$ of European students. The difference is significant at $p=.002$.

- Refuse to Register Shareware. In this scenario, 64.9\% of American respondents answered "yes" compared to $80.9 \%$ of Europeans. This difference is significant at $p=.001$.

- Share Password. When asked if they would give their university computer password to a non-student friend, 32.8\% Americans answered "yes" compared to $49.4 \%$ of Europeans. The difference was significant at $p=.001$.

- Generate Inaccurate Data. Of American students, $37.5 \%$ said they would write the program compared to $68.5 \%$ of European students, a difference that is significant at $p=.000$.

- Fail to Report Interest Error. While only $7.1 \%$ of American students agreed with the action, $16.3 \%$ of European students agreed. The difference is significant at $p=.006$.

- Copy Spreadsheet Package for Home Use. In this scenario, 72.8\% American students would do it, compared to $85.3 \%$ of European students, a significant difference at $p=.004$.

- Access Payroll Records. Responses revealed that $20.7 \%$ of American students would access the records compared to $43.5 \%$ of European students. The difference is significant at $p=.000$.

- Use Company PC. Of American students, 35.1\% would do the same, compared to $51.2 \%$ of European students, a difference that is significant at $p=.002$. 
- Porn Site Usage. In this scenario, $61.1 \%$ of American students would fire employees browsing pornographic websites, while $40.6 \%$ of European students would do so. From the employee's perspective, $4.2 \%$ of American students report they would browse such sites at work compared to $24.8 \%$ of European students. The differences between the two groups on both actions is significant at $p=.000$.

- Make and Sell Music CD. In the collected responses, 36.1\% of American students and 21.3\% of European students would take the same action. The difference is significant at $p=.002$.

\section{DISCUSSION}

In the overall results, it is interesting to note that both American and European students appear to approve of such behaviors as copying software or not registering shareware. This result might be explained by earlier work which suggested that such violations for personal use were more readily accepted than when violations were for distribution purposes [30].

In the general test of differences between American and European students, it was discovered that American students view 13 of 22 scenarios as more unethical than European students. Using Whitman et al.'s [35] categories to synthesize the 13 scenarios provides a simpler means for discussion. Six of the issues are related to the misuse of organizational resources, five involve license infringement, and three reflect forms of illicit use. The fairly even representation of issues suggests that the American students were overall less tolerant of the behaviors reported.

On the other hand, the three scenarios rated as more unethical by the European students all fall into the misuse of organizational resource category. It is also interesting to note the difference in means for two of the three scenarios Review Critical Email and Fire Porn Site User because they were the widest spread of means of all 22 scenarios. This finding does not negate the suggestion that overall American students appeared less tolerant, but it certainly lends itself to further investigation.

As this study was exploratory in nature, no specific research was found to help explain the results indicating differences in judgment toward ethical dilemmas between American and European students. However, the results regarding employer monitoring of company resources by Hilton et al. [15] seem to contradict the current results. Specific to those types of scenarios, the European students rating those behaviors as more unethical than American students while in the Hilton et al. study, American bank employees rated them as more unethical than their counterparts from Oman and South Korea.

In future studies, our results should be reviewed by comparing national laws and attitudes toward a variety of ethical dilemmas from the counterpart countries, especially since it has been shown that potential consequences is important in ethical decision making [30].

Another perspective would be to consider the previous ethical training of the students in the sample. It is plausible that differences in the amount of prior ethics training in the IT curriculum could influence students' judgments.

In terms of actions that would be taken by students in the hypothetical cases, Americans differed significantly from Europeans in 11 of 22 scenarios. The biggest differences, by a margin of more than $20 \%$, occurred in four of those scenarios. American students were less likely to deceive external auditors, access payroll records, or browse pornographic websites at work than European students. On the other hand, American students were more likely than their counterparts to fire an employee for browsing pornographic websites. Future research might focus on uncovering specific factors that might influence students' personal ethical decisions. For example, culture or societal views about the acceptable use of pornographic material may vary widely among nations.

It is also important to note that the American and European students made similar, at least not significantly different, choices about their personal ethical actions indicating that perhaps some issues are more universally recognized as acceptable or unacceptable. Using Whitman et al.'s [35] categories to classify the areas of agreement, six of the 11 similar responses reflect illicit use. Four fall into misuse of organizational resources and only one involves a license infringement. This result might suggest that software and other license infringement be further explored with regard to national laws and cultural norms.

\section{CONCLUSION}

The findings reported have important implications for both organizations and educators. Organizations that assemble $\underline{\text { multinational teams of IT specialists should be aware that an employee's judgment of ethical issues may be }}$ 


\section{Issues in Information Systems}

Volume XII, No. 1, pp. 78-87, 2011

influenced by nationality. Ethics training for employees should address a wide variety of situations, some of which might previously have been taken for granted. Additionally, educators can use these results to focus more attention on specific ethical dilemmas which may appear to different students as varying in levels of seriousness.

This study is not without limitations. One limitation is the convenience sample. Although it was our intent to study IT students, we were limited in accessibility to a wider European audience. With regard to the European students, the number represented in the total sample was similar to that number of Americans; however, future studies should strive for a larger sample from each country represented.

The rise in computer usage results in increasing opportunities for consciously or unconsciously engaging in unethical or illegal behavior. This issue is especially important for IT students, who will become future IT professionals. IT students are likely to encounter a myriad of situations before and after they enter the job market that will challenge their ethical judgment.

In this exploratory research, significant differences in rating the ethicality of scenarios between American students and their European counterparts were revealed along with significant differences in their personal ethical choices. The findings pave the way for a variety of future research opportunities.

\section{REFERENCES}

1. Ahmed, M. M., Kung Young, C., \& Eichenseher, J. W. (2003). Business students' perception of ethics and moral judgment: A cross-cultural study. Journal of Business Ethics, 43(1/2), 89-102.

2. Batten, J., Hettihewa, S., \& Mellor, R. (1999). Factors affecting ethical management: Comparing a developed and a developing economy. Journal of Business Ethics, 19(1), 51-59.

3. Blodgett, J. G., Long-Chuan, L., Rose, G. M., \& Vitell, S. J. (2001). Ethical sensitivity to stakeholder interests: A cross-cultural comparison. Journal of the Academy of Marketing Science, 29(2), 190-202.

4. Business Software Alliance. (2007). Global software piracy study. Retrieved April 4, 2010, from http://www.bsa.org/idcstudy.aspx

5. Business Software Alliance. (2010). Global Piracy Study 2010.

6. Bynum, T. (2008). Computer and information ethics. E. N. Zalta (Ed.) The Stanford Encyclopedia of Philosophy. Retrieved from http://plato.stanford.edu/entries/ethics-computer/

7. Chung, K., Eichenseher, J., \& Taniguchi, T. (2008). Ethical perceptions of business students: Differences between East Asia and the USA and among Confucian cultures. Journal of Business Ethics, 79(1/2), 121-132.

8. Cohen, E., \& Cornwell, L. (1989). College students believe piracy is acceptable. CIS Educator Forum: A Quarterly Journal, 1(3), 2-5.

9. Conger, S., Loch, K. D., \& Helft, B. L. (1995). Ethics and information technology use: A factor analysis of attitudes to computer use. Information Systems Journal, 5, 161-184.

10. Ford, R. C., \& Richardson, W. D. (1994). Ethical decision making: A review of the empirical literature. Journal of Business Ethics, 13(3), 205-221.

11. Freestone, O., \& Mitchell, V. W. (2004). Generation Y attitudes towards e-ethics and internet-related misbehaviors. Journal of Business Ethics, 54(2), 121-128.

12. Gerlach, J. H., Kuo, F.-Y. B., \& Lin, C. S. (2009). Self-sanction and regulative sanction against copyright infringement: A comparison between U.S. and China college students. Journal of the American Society for Information Science and Technology, 60(8), 1687-1701.

13. Gotterbarn, D. (2001). Informatics and professional responsibility. Science and Engineering Ethics, 7(2), 221230.

14. Harris, A. L. (2000). IS ethical attitudes among college students: A comparative study. In The Proceedings of the Information Systems Education Conference 2000, v 17 (Philadelphia): §801.

15. Hilton, T., Oh, S.-H. D., \& Al-Lawati, H. (2006). Information systems ethics in the triad. Journal of Computer Information Systems, 46(4), 78-102.

16. Johnson, D. (1985). Computer ethics (1st ed.). Englewood Cliffs, NJ: Prentice-Hall.

17. Kini, R. B., Ramakrishna, H. V., \& Vijayaraman, B. S. (2004). Shaping of moral intensity regarding software piracy: A comparison between Thailand and U.S. students. Journal of Business Ethics, 49(1), 91-104.

18. Kini, R. B., Rominger, A., \& Vigayaraman, B. (2000). An empirical study of software piracy and moral intensity among university students. Journal of Computer Information Systems, 40(3), 62-72. 


\section{Issues in Information Systems}

Volume XII, No. 1, pp. 78-87, 2011

19. Kruger, R. (2003). Discussing cyber ethics with students is critical. Social Studies, 94(4), 188-189.

20. Loe, T. W., Ferrell, L., \& Mansfield, P. (2000). A review of empirical studies assessing ethical decision making in business. Journal of Business Ethics, 25(3), 185-204.

21. Loviscky, G., Trevino, L., \& Jacobs, R. (2007). Assessing managers' ethical decision-making: An objective measure of managerial moral judgment. Journal of Business Ethics, 73(3), 263-285.

22. Maner, W. (1980). Starter kit in computer ethics. Hyde Park, NY: Helvetia Press and the National Information and Resource Center for Teaching Philosophy.

23. Mason, R. O. (1986). Four ethical issues of the information age. MIS Quarterly, 10(1), 5-12.

24. Moores, T., \& Dhillon, G. (2000). Software piracy: A view from Hong Kong. Communications of the ACM, 43(12), 88-93.

25. O'Fallon, M. J., \& Butterfield, K. D. (2005). A review of the empirical ethical decision-making literature: 19962003. Journal of Business Ethics, 59(4), 375-413.

26. Oz, E. (1990). The attitude of managers-to-be toward software piracy. OR/MS Today, 17(4), 24-26.

27. Paradice, D. B. (1990). Ethical attitudes of entry-level MIS personnel. Information \& Management (18), 143151.

28. Peace, A. G., Galletta, D. F., \& Thong, J. Y. L. (2003). Software piracy in the workplace: A model and empirical test. Journal of Management Information Systems, 20(1), 153-177.

29. Peslak, A. (2006). PAPA revisited: A current empirical study of the Mason framework. Journal of Computer Information Systems, 46(3), 117-123.

30. Peslak, A. R. (2008). Current information technology issues and moral intensity influences. Journal of Computer Information Systems, 48(4), 77-86.

31. Siponen, M. T., \& Vartiainen, T. (2005). Attitudes to and factors affecting unauthorized copying of computer software in Finland. Behaviour \& Information Technology, 24(4), 249-257.

32. Solomon, S. (1990). The effect of demographic factors on attitudes toward software piracy. Journal of Computer Information Systems, 30(3), 41-46.

33. Sparks, J., \& Pan, Y. (2010). Ethical judgments in business ethics research: Definition, and research agenda. Journal of Business Ethics, 91(3), 405-418.

34. The role of technology in reducing illegal file-sharing: A university perspective: Hearing before the Committee on Science and Technology, U.S. House of Representatives, $110^{\text {th }}$ Cong. (2007). Retrieved July 30, 2010 from http://science.house.gov/publications/hearings_markups_details.aspx?NewsID=1846.

35. Whitman, M. E., Townsend, A. M., \& Hendrickson, A. R. (1999). Cross-national differences in computer-use ethics: A nine-country study. Journal of International Business Studies, 30(4), 673-687.

36. Woodward, B., Davis, D. C., \& Hodis, F. A. (2007). The relationship between ethical decision making and ethical reasoning in information technology students. Journal of Information Systems Education, 18(2), 193202. 
Volume XII, No. 1, pp. 78-87, 2011

Appendix A

\begin{tabular}{|c|c|}
\hline Short Name & Ethical Scenario \\
\hline $\begin{array}{l}\text { Review Critical Email - } \\
\text { Manager* }\end{array}$ & $\begin{array}{l}\text { A manager of a company reviews email messages sent by subordinates. Policy states that the system is not to } \\
\text { be used for private purposes. When he finds an employee sending messages critical of management, the } \\
\text { manager reprimands him. }\end{array}$ \\
\hline Send Critical Email-Employee & $\begin{array}{l}\text { An employee sends email messages critical of management even though company policy states that email is } \\
\text { to be used only for company business and may be reviewed by managers. }\end{array}$ \\
\hline Change Bank Account Status & $\begin{array}{l}\text { A bank employee realizes he has accidentally overdrawn his checking account and will have to pay } \$ 25 \text { for } \\
\text { overdrawn checks. He changes his account status until he makes a deposit so that no overdraft fees will be } \\
\text { assessed. }\end{array}$ \\
\hline Refuse to Register Shareware* & $\begin{array}{l}\text { A man downloads a shareware program which requires anyone using it to register and pay a small fee. He } \\
\text { uses the program daily and decides not to register his use since no one will ever know. }\end{array}$ \\
\hline Copy Word Processing Program & $\begin{array}{l}\text { A woman purchases the latest upgrade of a word processing program that she owns. The license states that } \\
\text { the old version is to be discarded or kept only for backup purposes. She loads the old version onto her } \\
\text { secretary's computer since she does not have a word processing program. }\end{array}$ \\
\hline Change Class Data & $\begin{array}{l}\text { A student changes the data in a file needed in a class competition to favor his team. Just before the results are } \\
\text { due to the professor, he changes the data back to its original value and his team wins. }\end{array}$ \\
\hline Share Password* & $\begin{array}{l}\text { A university student gives his password to a friend who is not a student allowing the friend to use the school's } \\
\text { computer several hours a week to play computer games. }\end{array}$ \\
\hline Spread Virus for Test & $\begin{array}{l}\text { A graduate student is writing a paper on the effects of computer viruses. She writes a program that releases a } \\
\text { PEACE message through email. The message would not affect the receivers' data but would interrupt their } \\
\text { screen. She does this to test how fast a simple, non-destructive virus can spread. }\end{array}$ \\
\hline Generate Inaccurate Data* & $\begin{array}{l}\text { A programmer is asked to write a program which he knows will generate inaccurate information for the } \\
\text { company's external auditors. When he questions his manager, he is told to write the program or be } \\
\text { reassigned. He writes the program. }\end{array}$ \\
\hline Send Email SPAM & $\begin{array}{l}\text { In a company that has no policy on the use of email, an employee sends hundreds of SPAM messages to } \\
\text { political donors. }\end{array}$ \\
\hline Reprimand SPAM Sender & $\begin{array}{l}\text { A manager of a company that has no policy on email use reviews email messages sent by subordinates. When } \\
\text { he finds an employee has sent hundreds of SPAM messages to political donors, he reprimands the employee. }\end{array}$ \\
\hline Fail to Report Interest Error* & $\begin{array}{l}\text { A maintenance programmer for a loan company finds an error in a program that computes interest. He } \\
\text { estimates that } 25-50 \text { cents is added to each bill per month. He is very busy and decides not to report the error } \\
\text { to management since it is such a small amount. }\end{array}$ \\
\hline $\begin{array}{l}\text { Copy Spreadsheet Pkg for } \\
\text { Home* }\end{array}$ & $\begin{array}{l}\text { A company purchases a spreadsheet package for an employee's use on the job. The license says this is } \\
\text { licensed only to the employee's machine. The employee makes a copy to use at home since she often takes } \\
\text { work home. }\end{array}$ \\
\hline Release Shareware Virus & A man creates a virus to force users to register for a shareware program he created. \\
\hline Access Payroll Records* & $\begin{array}{l}\text { A salesperson believes she is not being paid the same as other salespeople. She accesses the payroll records } \\
\text { on the main computer and concludes she is getting paid appropriately. She makes no other use of the } \\
\text { information. }\end{array}$ \\
\hline Use Company PC * & $\begin{array}{l}\text { An employee is having financial difficulties. His company has cut employees hours and encouraged them to } \\
\text { look for part time work. This employee is consulting for a small business and uses the other company's } \\
\text { computers to build a database for his consulting client. }\end{array}$ \\
\hline $\begin{array}{l}\text { Create Website to Collect } \\
\text { Personal Data }\end{array}$ & $\begin{array}{l}\text { A person is asked to create a web site to collect personal information from internet surfers. He is aware the } \\
\text { company sells the data to advertisers for a profit and may use it send SPAM and sexually explicit mailings to } \\
\text { unwitting people. He creates the web site. }\end{array}$ \\
\hline Fire Porn Site User* & $\begin{array}{l}\text { An employee of a company that allows limited personal use of the internet visits pornographic sites } \\
\text { frequently. }\end{array}$ \\
\hline View Porn Sites at Work* & $\begin{array}{l}\text { The manager of an employee found to frequently visit pornographic websites fires the employee. The } \\
\text { company allows limited personal use of the internet. }\end{array}$ \\
\hline $\begin{array}{l}\text { Use Company PC for Offshore } \\
\text { Gambling }\end{array}$ & $\begin{array}{l}\text { An employee uses an offshore website for gambling activity. Gambling is illegal in the state where he is } \\
\text { located. }\end{array}$ \\
\hline $\begin{array}{l}\text { Use Trademarks without } \\
\text { Permission }\end{array}$ & $\begin{array}{l}\text { A web site designer posts a seal that says "Approved by the BBB" and a seal indicating the "Fisher-Price" } \\
\text { trademark to increase sales without permission to use either name. }\end{array}$ \\
\hline Make and Sell Music CD* & $\begin{array}{l}\text { A woman downloads music from a file-swapping site using another person's account. She uses the music to } \\
\text { make music CDs for her friends and charges } \$ 5 \text { each. }\end{array}$ \\
\hline
\end{tabular}

